\title{
A Comparison between the Effect of Cooperative Learning Teaching Method and Lecture Teaching Method on Students' Learning and Satisfaction Level
}

\author{
Farzad Mohammadjani ${ }^{1} \&$ Forouzan Tonkaboni $^{2}$ \\ ${ }^{1}$ Instructor, School of Educational Sciences, Payame Nour University (PNU), Tehran, Iran \\ ${ }^{2}$ School of Educational Sciences, Payame Nour University (PNU), Tehran, Iran \\ Correspondence: Farzad Mohammadjani, School of Educational Sciences, Payame Nour University (PNU), \\ Tehran, P.O.Box 19395-3697, Iran. Tel: 98-917-200-7426. E-mail: Mohamadjanifarzad@gmail.com
}

\author{
Received: February 8, 2015 Accepted: March 9, 2015 Online Published: August 26, 2015 \\ doi:10.5539/ies.v8n9p107 URL: http://dx.doi.org/10.5539/ies.v8n9p107
}

\begin{abstract}
The aim of the present research is to investigate a comparison between the effect of cooperative learning teaching method and lecture teaching method on students' learning and satisfaction level. The research population consisted of all the fourth grade elementary school students of educational district 4 in Shiraz. The statistical population included 120 students (60 female and 60 male) of fifth grade elementary school that were selected randomly. The research method was semi-experimental and the research tools included a 40-item exam aimed at evaluating the students' learning level and also a questionnaire aimed at measuring student's satisfaction level that included 25 items. Validity was calculated by asking 14 educational science professors and 12 members of the board of education to examine the content of the items. The reliability of the test was confirmed through retesting $(\mathrm{r}=.88)$. For data analysis, $\mathrm{t}$-test and variance analysis were used by utilizing SPSS software. The results showed that the cooperative learning teaching method has a higher effect on students learning than the lecture teaching method. Also the results showed that the cooperative learning method results in higher satisfaction in students that the lecture teaching method. Female students had higher satisfaction and learning levels in cooperative learning teaching method than male students did.
\end{abstract}

Keywords: teaching method, cooperative learning, lecture, students satisfaction

\section{Introduction}

Education plays an important role in the complicated world of today. In conditions in which countries worldwide think their development relies on the development of education systems, traditional teaching methods cannot provide them with the development and transformation they want (Mohaffeghian et al., 2012).

The increase in the quality and academic achievement is one of the main goals of education and teachers can play an important and effective role in the academic achievement of students by selecting the proper methods (Hoseini, 2007). Traditional methods consider classrooms as places where the role of teachers is merely to provide information to their students. Students work individually or competitively. In this method, students are practically trying to increase their knowledge. In such classes, goals are personal which contradicts with cooperative classes. Cooperative learning is an educational method in which, students cooperatively work towards achieving common goals. However, schools today, feel the need to teach social skills to students; while few students are skilled at social skills, many need to learn them (Hill, 2000).

Many definitions are provided in educational literature for direct teaching method or lecture teaching method. Kassop (2003) has defined direct teaching as a method in which, a teacher discusses, shows, models, demonstrates, and teaches the skills that are to be learned. In this method, the key element is the teacher. It is the teacher who is responsible for the learning situation and who leads the course. In traditional methods that are known as inactive methods in today's world, a teacher plays an active role in the teaching process and states everything in a fully oral manner and the students should only listen to him/her and memorize what they hear. Under such conditions, the necessary requirement for the development of learners' social personalities is not provided and even their academic achievement and intellectual development are impacted by these conditions. As a result, the topic of active teaching methods and active learners, has found a special place in educational 
discussions today. Of course, several factors prevent the social development and academic achievement of students and inactive teaching methods are one of them (Keramati, 2003).

Cooperative learning was unknown until 1960. At this time, although competitive learning dominated educational thoughts, individual learning that was mainly based on the works of Skinner about programmed learning and behavioral changes, was challenged. Today's educational performances and thoughts have changed and now cooperative learning is accepted as a suitable educational method that is accepted for all educational levels. Currently, cooperative learning is used in schools and universities worldwide for different topics and for all age groups. Little literature can be found on teaching methods, teacher magazines, or teaching materials that have not discussed cooperative learning, and to be brief, cooperative learning method is one of the successful events in psychology and educational science (Gillies et al., 2008).

According to Payne and Whittaker (2000), one of the most important approaches for activating students in a learning process is the use of study groups and discussion opportunities. It seems that cooperative learning can provide such an opportunity better. The reason is that in this method, students work in small heterogeneous groups to achieve a common goal and try to maximize theirs and their partners' learning level (Gokal, 1995). Cooperative learning is not the grouping of students based on equal skills; rather, the heterogeneity of the group in terms of race, language, culture, intelligence, and academic achievement increases the efficiency of the method (Cohen, 2003). Cooperative learning only improves students' achievement when their teacher places them in small groups and states a clear goal for them, and this improvement is achieved when all group members master the educational content. In other words, if the possibility exists that one or more group members find an answer and share it with the others, or perform the intellectual part of the group assignment while others only observe, then in that case, cooperative learning has not been achieved (Slavin, 2004). Many researches have been conducted concerning the effect of cooperative learning and its comparison with other traditional teaching methods, few of which will be mentioned here.

Winston (2002), in a study performed on fifth grade students of different cultures in the USA, concluded that cooperative learning has a positive effect on students attitude towards math and their academic achievement in this course. In a study, Nichols (2002) examined the effect of one cooperative teaching method on the motivation and academic achievement of 80 geometry class high school students. The results showed that the students in the cooperative learning group were more efficient compared to the students in the control group and had a goal-oriented learning. They also valued the geometry course more and had higher academic achievement.

Bamberger (2005) showed that cooperative learning grows the cooperation ability of group members and results in students' higher academic achievement. Keramati (2002) investigated the effect of cooperative learning on the development of students' social and math skills and concluded that the positive changes in the experimental group compared to the group taught traditionally were significant. Yaryari et al. (2008) showed that the cooperative learning method has a positive influence on students' social skills and academic achievement but no such influence was observed in their self-esteem. Mirzabigi et al. (2008) concluded in their research that the durability of the learned materials is higher in the experimental groups compared to the control groups and the difference was also significant. Rasuli et al. (2011) showed that the cooperative group had a positive and significant difference with the lecture group in terms of creativity and academic achievement. In addition, strong, average, and weak students have different creativity levels in their academic achievement based on intervention.

Shekari (2012) demonstrated that cooperative learning method has a higher influence on the development of the social skills of students compared to traditional teaching methods. The research results of Eslamiyan et al. (2013) showed that the average points of learning evaluation test given to the students was significantly higher in group discussion method compared to lecture teaching method. Meanwhile, the results showed that the satisfaction level was higher in students who had been taught in group discussion method compared to lecture teaching method.

\subsection{Research Hypotheses}

- There is a significant difference between the learning levels of students taught through lecture teaching methods and cooperative teaching method.

- There is a significant difference between the students' satisfaction level from the two teaching methods of lecture and cooperative learning.

- Gender was important in the effect of the teaching methods compared to the two variables of increased learning and satisfaction of students. 


\section{Research Method}

Due to the use of untouched groups, the present research method was of semi-experimental and double-group type (experimental and control). Given the semi-instructional nature of the research and the priority of the internal control and validity which have based on generalization, the statistical research population included the elementary school students of area four of Shiraz. Two male students' classes, one as the experimental and the other as the control group, were chosen and the same procedure was done for the female students. For the experimental groups, the cooperative teaching method (with students in small groups of 5), and for the control groups, the lecture teaching method were performed. The number of students in each class was 30 . In other words, 60 students were being taught through the lecture teaching method and another 60 were being taught through the cooperative learning method. The course type for this research was experimental science. At the end, in both teaching methods, in order to evaluate the learning level from the lessons (or evaluate academic achievement in the cognitive area), a 40 -item multiple-choice test was used. To score the test, each item was allotted 2.5 points. The range for the evaluation of students' learning level ranged from 0 to 100 . The measurement tool for students' satisfaction level from the teaching method was a 25 -item questionnaire created by the researchers which included the subscales of motivation to participate in learning, compliance with teaching and learning principles, creating a spirit to learn and be creative, create a spirit to inquire and demand and test the course's materials ( 5 points were allotted for each subscale). The questionnaire was based on the 5 option scale of Likert. Points ranging from 0 to 5 were allotted for each question and the points' range was $0-100$. To provide the questions for the satisfaction from the teaching questionnaire, valid scientific sources in the areas of teaching and learning methods were used. In order to examine the validity of this questionnaire, the comments from a number of educational science professors $(\mathrm{N}=14)$ and a number of experimental science experts $(\mathrm{N}=7)$ were used. For a final confirmation of the questionnaire, the test-retest method was used and a high correlation of $(\mathrm{r}=0.88)$ was obtained. For data analysis, the statistics at the two levels of descriptive and inferential were calculated. In the descriptive statistics, frequency, average, and standard deviation and in the inferential statistics, the independent samples t-test, variance analysis, and double factor variance analysis were used.

Table 1. Comparison of the students' grades on the learning evaluation test in the methods of lecture teaching and cooperative learning

\begin{tabular}{lllllll}
\hline Sig. & T & df & $\begin{array}{l}\text { Std. } \\
\text { deviation }\end{array}$ & Average & Number & Teaching method \\
\hline \multirow{2}{*}{0.00} & -8.89 & 118 & 21.4 & 64.2 & 60 & lecture \\
& & 118 & 14.7 & 58.10 & 60 & Cooperative learning \\
\hline
\end{tabular}

Based on the findings in Table 1, the significance level $(\mathrm{sig}=0.00)$ is smaller than the test level $(\alpha=0.05)$. Therefore, the difference in the averages is significant. In other words, the average of the points of the students' learning evaluation test in the cooperative learning method was significantly higher compared to the lecture teaching method. 
Table 2. Comparison of the average of the grades of students in the test of the evaluation of satisfaction level from the two teaching methods of lecture and cooperative learning

\begin{tabular}{|c|c|c|c|c|c|c|c|c|c|}
\hline \multirow[b]{2}{*}{ Sig. } & \multirow[b]{2}{*}{$\mathrm{T}$} & \multirow[b]{2}{*}{ df } & \multicolumn{3}{|c|}{ Cooperative learning } & \multicolumn{3}{|c|}{ Lecture } & \multirow[b]{2}{*}{ Subscale } \\
\hline & & & $\begin{array}{c}\text { Std. } \\
\text { deviation }\end{array}$ & Average & Number & $\begin{array}{c}\text { Std. } \\
\text { deviation }\end{array}$ & Average & Number & \\
\hline 0.00 & -10.75 & 118 & 5.10 & 20.09 & 60 & 7.3 & 11.35 & 60 & $\begin{array}{c}\text { Create interest } \\
\text { and encourage } \\
\text { participation }\end{array}$ \\
\hline 0.017 & -10.29 & 118 & 4.4 & 19.43 & 60 & 5.92 & 12.50 & 60 & $\begin{array}{l}\text { Compliance with } \\
\text { teaching and } \\
\text { learning } \\
\text { principles }\end{array}$ \\
\hline 0.00 & -12.54 & 118 & 4.63 & 20.64 & 60 & 6.13 & 11.82 & 60 & $\begin{array}{l}\text { Create a spirit of } \\
\text { creativity and } \\
\text { innovation }\end{array}$ \\
\hline 0.021 & -16.39 & 118 & 4.73 & 21.85 & 60 & 5.12 & 11.42 & 60 & $\begin{array}{c}\text { Create a spirit of } \\
\text { inquiry and } \\
\text { demand }\end{array}$ \\
\hline 0.00 & -12.65 & 118 & 3.82 & 21.30 & 60 & 6.75 & 12.34 & 60 & Evaluation test \\
\hline 0.00 & -12.44 & 118 & 22.68 & 103.25 & 60 & 31.22 & 59.4 & 60 & $\begin{array}{c}\text { The sum of five } \\
\text { subscales }\end{array}$ \\
\hline
\end{tabular}

According to Table 2, the sum of the five subscales' significance level (sig=0.00) is smaller than the test level $(\alpha=0.05)$, which implies that the average difference is significant. In other words, the average points of students' satisfaction of cooperative learning method were much higher compared to lecture teaching method.

Table 3. Average of students' learning level based on gender and teaching method

\begin{tabular}{ccc}
\hline $\begin{array}{c}\text { Cooperative learning } \\
\text { teaching method }\end{array}$ & Lecture teaching method & Gender \\
\hline 80.25 & 58.21 & Male \\
89.95 & 70.2 & Female \\
\hline
\end{tabular}

Table 4. Double-factor variance analysis results (dependent variable: learning)

\begin{tabular}{cccccc}
\hline Sig. & F & Average of square & df & Sum of square & Source \\
\hline 0.01 & 17.32 & 1276.52 & 1 & 1276.52 & gender \\
0.00 & 12.97 & 955.37 & 1 & 955.37 & method \\
0.24 & 0.64 & 47.87 & 1 & 47.87 & Gender $\times$ method \\
- & - & 73.66 & 1 & 8544.96 & Error \\
\hline
\end{tabular}

Table 5. Average of students' satisfaction from teaching based on gender and teaching method

\begin{tabular}{ccc}
\hline $\begin{array}{c}\text { Cooperative learning } \\
\text { teaching method }\end{array}$ & Lecture teaching method & Gender \\
\hline 97.61 & 51.73 & Male \\
108.89 & 67.07 & Female \\
\hline
\end{tabular}


Table 6. Double factor variance analysis (dependent variable: satisfaction from teaching)

\begin{tabular}{cccccc}
\hline Sig. & F & Average of square & df & Sum of square & source \\
\hline 0.15 & 3.14 & 214.42 & 1 & 214.42 & gender \\
0.001 & 15.35 & 1045.15 & 1 & 1045.15 & method \\
0.34 & 2.28 & 155.77 & 1 & 155.77 & Gender $\times$ method \\
& & 68.07 & 116 & 7896.34 & error \\
\hline
\end{tabular}

Hypothesis 3: Gender was important in the effect of the teaching methods compared to the two variables of increased learning and satisfaction of students. According to the findings of Tables 3 and 4, and given the F values, the average points of students in the learning evaluation test is higher for girls and also higher in the cooperative learning method. But no significant interaction effect between gender and teaching method is observed given the higher level of the significance level ( $\operatorname{sig} 0.240)$ compared to the test level $(\alpha=0.05)$. This means that the observed difference exists in both the lecture and cooperative learning methods for both genders.

According to the findings of Tables 5 and 6, and given the F values, no significant difference is seen in the two genders between the points of students in the test of the satisfaction from teaching method; however, the satisfaction level of both genders was significantly higher from cooperative learning method compared to lecture teaching method. In addition, no significant interaction is seen between gender and teaching method in this relation.

\section{Discussion}

Investigation of the first hypothesis shows that there is a significant difference between the two methods of lecture teaching and cooperative learning. In cooperative learning method, since comments, thoughts, and beliefs of individuals are different, a conflict is raised which, if managed properly, will increase development and learning. In any group discussion, first the participants state their ideas, offer their inferences, listen to other peoples' comments, reasons, and opinions, and make a conclusion.

In cooperative learning, individuals get to discuss matters and each individual expresses his ideas and opinions about any subject. In other words, since matters are assessed and discussed with reasons and each person defends his/her opinion, a positive and synergistic atmosphere exists and people defend each other and complement each other's thoughts. This will make learning deeper and better and the existence of heterogeneous group members will create new ideas and thoughts and matters will be better explored and learning will increase. In a process of cooperative learning, people will get the chance to state their opinions and become familiarized with their friends' opinions regarding different topics. These findings are in line with the research findings of Winston (2002), Nichols (2002), Bamberger (2005), Yaryari et al. (2008), Mirzabigi et al. (2008) and Rasuli et al. (2011).

Investigation of the second hypothesis shows that, generally, the satisfaction of students in the cooperative learning teaching method is higher compared to students who are taught by the lecture teaching method. Given that in cooperative learning teaching method, students can state theirs thoughts, interests, and ideas better, and find out about their classmates' and friends' opinions, this teaching method will make students get more motivated while learning, increase their excitement, encourage them to ask more questions. In cooperative teaching method, since students have higher degrees of freedom, they become more interested and are more satisfied than in lecture teaching method. In this method, since students ask questions of each other, listen to the answers, their creativity and innovation spirits grow. Therefore, all these cause students to be more satisfied compared to lecture teaching method. These results are in line with the results of the researches of Keramati (2002), Shekari (2012), and Eslamiyan et al. (2013).

Concerning the third hypothesis, the results show that the learning level is higher among girls in both teaching methods compared to boys, but the factor analysis shows no significant interactive effect between gender and teaching method. It can be argued that, generally, the higher level of questioning among female students can relatively increase their learning level in both teaching methods compared to male students.

\section{References}

Bamberger, M. (2005). Cooperative Learning and case study: Dose the combination improve student's perception of problem-solving and decision making s kills? Journal of Nurse Education Today, 25, 238-246. http://dx.doi.org/10.1016/j.nedt.2005.01.010

Cohen, E. G. (2003). Designing Group work. Retrieved from http://www.coalitionofessentialschools.org 
Eslamiyan, H., Saeedi, R. M., \& Jarosz, M. J. (2013). Comparison of the effects of group discussion and lecture teaching methods on students learning and satisfaction level from teaching in the courses of theology. Research on Curricula, 2(11), 13-23.

Gillies, R. M., Ashman, A. F., \& Terwel, J. (2008). The teacher's role in implementing cooperative Learning in the classroom. New York: Springer Science Business Medi, LLC. http://dx.doi.org/10.1007/978-0-387-70892-8

Gokal, A. (1995). Cooperative Learning. Collaborative Learning Education, 1(7).

Hill, K. A. (2000). Cooperative learning as a mean of improving social skill among middle grade student. Retrieved from http://www.Usoe. K12.ut.US/oals 2000/Kathy-hill-cooperative Learning.htm

Hoseini, A. A. (2008). Evaluating the effect of teachers' creativity educational program onacademic achievement and self-esteem of students. Educational Innovations, 6(23), 147-168.

Kassop, M. (2003). Ten ways online education matches or surpasses, face-to-face learning. Book of Educational.

Keramati, M. (2001). Investigating the effect of cooperative learning on the development of social skills and learning of math in 5th grade students (Unpublished doctoral dissertation). Tarbiyat Moallem University.

Mirzabigi, M. (2008). Comparison of the effects of cooperative learning method, cooperative learning with discussion principles, and lecture method on fifth grade elementary school students' academic achievement in geography course.

Mohagheghian, Sh., Rahimi, M., \& Hamadi, Gh. (2012). Recognition and application of new teaching models among the humanities faculty members. Research in Curriculum Planning, 4.

Nichols, J. D. (2002). The Effect of cooperative learning on student achievement and motivation in a high school geometry class. Contemporary Educational Psychology, 21, 467-476. http://dx.doi.org/10.1006/ceps.1996.0031

Payne, \& Whittaker, L. (2000). Developing essential study skills. Prentice-Hall, England.

Rasuli. (2011). Comparison of the effect of cooperative learning method and lecture teaching methods on the creative thinking and academic achievement in career and technology course of third grade secondary school female students of Yazd city. New Educational Thoughts, Faculty of Educational Science and Psychology, Alzahra University.

Shekari, A. (2001). The effect of cooperative learning on the development of students' social skills. Journal of Teaching Strategies, 1(5), 31-37.

Slavin, R. E. (2004). Translating research into widespread practice: The case of success for all. ERIC.

Winston, V. (2002). Effect of cooperative Learning on Achievement and Attitude among Student of Color. Journal of Educational Research, 95, 220-229.

Yaryari, F., Kadivar, P., \& Mirzakhani, M. (2008). Investigating the effect of cooperative learning teaching method on self-esteem, social skills, and academic performance of students. Journal of Tabriz University, 10 .

\section{Copyrights}

Copyright for this article is retained by the author(s), with first publication rights granted to the journal.

This is an open-access article distributed under the terms and conditions of the Creative Commons Attribution license (http://creativecommons.org/licenses/by/3.0/). 